\title{
Serological and molecular diagnosis of hepatitis $B$ virus
}

\author{
S Durgadevi, Rahul Dhodapkar, Subash Chandra Parija* \\ From First International Science Symposium on HIV and Infectious Diseases (HIV SCIENCE 2012) \\ Chennai, India. 20-22 January 2012
}

\section{Background}

Hepatitis B is a potentially life threatening liver infection which leads to millions of deaths annually. Serological and molecular assays for hepatitis B virus are the major diagnostic tools. Dried blood spot (DBS), a minimally invasive procedure, is an alternative to serum and can be used for field based studies for molecular detection. The present aim of this study is to diagnose HBV infection by combination of serological and molecular methods from serum and dried blood spot.

\section{Methods}

Blood was collected from suspected cases of liver diseases attending JIPMER Hospital, during September 2010 to October 2011. The study group is divided into two each having 30 cases of hepatitis B surface marker positive and negative profile respectively. Samples were analyzed for complete serological tests (surface and core antigen) and PCR were performed on serum samples and DBS.

\section{Results}

Out of $30 \mathrm{HBsAg}$ positive cases screened by ELISA, 22 samples were found positive of HBV DNA by PCR method from serum, which includes 2 samples with only surface (HBsAg) and antibody to core antigen (IgM anti $\mathrm{HBc}$ ) positive. All these 22 positive cases were also been detected from DBS after storing the sample at $25^{\circ} \mathrm{C}$ for 4 and 7 days.

\section{Conclusion}

It is important to detect both serological and molecular markers to diagnose hepatitis B for appropriate management of disease Since dried blood spot yields comparable

\footnotetext{
* Correspondence: sdbrindha@gmail.com

Department of Microbiology, Jawaharlal Institute of Postgraduate Medical Education and Research (JIPMER), Puducherry, India
}

results to serum in detecting HBV DNA it can be used as convenient method of collecting samples than venous blood, particularly in resource limited settings.

Published: 4 May 2012

doi:10.1186/1471-2334-12-S1-P31

Cite this article as: Durgadevi et al: Serological and molecular diagnosis of hepatitis B virus. BMC Infectious Diseases 2012 12(Suppl 1):P31.
Submit your next manuscript to BioMed Central and take full advantage of:

- Convenient online submission

- Thorough peer review

- No space constraints or color figure charges

- Immediate publication on acceptance

- Inclusion in PubMed, CAS, Scopus and Google Scholar

- Research which is freely available for redistribution

Submit your manuscript at www.biomedcentral.com/submit

\section{() Biomed Central}

